\title{
Tyndale as promoter of figural allegory and figurative language: A Brief Declaration of the Sacraments
}

\section{Citation}

Simpson, William J. 2008. Tyndale as promoter of figural allegory and figurative language: A Brief Declaration of the Sacraments. Archiv Fur Das Studium Der Neueren Sprachen Und Literaturen 245(1): 37-55.

\section{Published Version}

http://www.archivdigital.info/ARCHIV.01.2008.037

\section{Permanent link}

http://nrs.harvard.edu/urn-3:HUL.InstRepos:42658684

\section{Terms of Use}

This article was downloaded from Harvard University's DASH repository, and is made available under the terms and conditions applicable to Open Access Policy Articles, as set forth at http:// nrs.harvard.edu/urn-3:HUL.InstRepos:dash.current.terms-of-use\#OAP

\section{Share Your Story}

The Harvard community has made this article openly available.

Please share how this access benefits you. Submit a story.

\section{Accessibility}


James Simpson

Harvard University

Tyndale as Promoter of Allegory and Figurative Language: A Brief Declaration of the Sacraments

Everyone knows that Lutheran evangelical writers, following Luther (1483-1546) himself, repudiated allegory and figurative readings of scripture wherever possible. Scripture was plain and incontrovertible. It interpreted itself, and was in any case easy to read because its only sense is the literal sense. In this short essay I show how William Tyndale both champions these views and, strikingly, repudiates them, in one treatise especially. In treating the sacrament of the Eucharist in his Brief Declaration on the Sacraments, Tyndale overturns all his own and all the standard evangelical hermeneutic and rhetorical persuasions. He does not remark on the striking inconsistency, but in this short essay I do remark on precisely that. I also try to understand why the Eucharist should be the place where the fissures of an evangelical hermeneutics become so startlingly visible.

\section{I}

William Tyndale (c. 1494-1536) published his Brief Declaration on the Sacraments between July 1533 and his imprisonment in May 1535 (prior to his 
execution in October 1536). ${ }^{1}$ We can be fairly certain of the terminus a quo of July 1533, since Tyndale wrote to John Frith (1503-1533) in the Tower in December 1532, warning Frith not to write on the Eucharist. “On the presence of Christ's body in the sacrament," Tyndale warned Frith, "meddle as little as you can, that there appear no division among us...My mind is that nothing be put forth, till we hear how you shall have sped. I would have the right use preached, and the presence to be an indifferent thing, till the matter might be reasoned in peace at leisure of both parties." 2 Frith was burned at the stake on 4 July 1533, a few days after having refused to recant. By that date, therefore, Tyndale knew how Frith had "sped." The terminus ad quem is determined by Tyndale's own arrest in May 1535. No copy of the first edition survives; the second edition was published in London, by Robert Stoughton in, apparently, 1548 (the edition is undated). ${ }^{3}$

The text forms a small part of a much larger conversation between evangelicals of different persuasions; between evangelicals and Catholics; and between English and Continental (especially German and Swiss) scholars. Within the larger debate about the sacraments provoked by Luther's Babylonian Captivity of the Church (1520), ${ }^{4}$ a more specific, three-cornered debate erupted concerning the Eucharist, among Catholics, Lutherans and followers of Ulrich Zwingli (14841531).

That debate consisted principally of argument about the following issues: what Christ meant by "is" in his statement " or "Hoc est corpus meum" (Matthew 26:26; Mark 14:22; Luke 22:19; and 1 
Corinthians 11:22); what was being eaten when the host was consumed (bread or the body of Christ?); where Christ was when the host was eaten (in the host (and therefore in many places), or only in one other place (i.e. in heaven)?); and what the correct spiritual posture of the communicant should be (experiencing the represented sacrifice of Christ, or only remembering that?; generating faith or only confirming it?).

In essence, there were three distinguishable positions, each with their nuances and varieties, but clearly distinguishable. The orthodox Catholic view ("transubstantiation") held that Christ meant "is" literally in saying "this is my body"; that Christ's body is therefore actually present in the Eucharistic host; and that communicant Christians are generating faith through representation of Christ's sacrifice in the Eucharist. The second, Lutheran view also held that Christ meant the word "is" literally, and also held that Christ is actually present in the communion wafer, but affirmed that that Christ's presence could not be described in Aristotelian terms of "transubstantiation." Further, the communicant is not re-experiencing the sacrifice of Christ, but the Eucharist can nevertheless generate faith. ${ }^{5}$ The third view, which might be called the Zwinglian view, argued that Christ was not using the word "is" literally when he said "This is my body": the word "is" should instead be understood figuratively. It really means "signifies." Christ is, therefore, only in one place when the host is being celebrated, and that place is in heaven. The communicant is not re-experiencing the sacrifice of Christ, but instead remembering it; the host is not generating faith 
so much as demonstrating that faith publicly. ${ }^{6}$ In short, each of these three positions entertained different ontological persuasions about the nature of the Eucharistic bread and wine; and the third, Zwinglian, view promoted a different rhetorical understanding of Christ's statement about the bread and wine, a rhetorical view designed to reflect an ontological persuasion.

Already in 1521 Luther's own followers in Wittenberg had broken from Luther's understanding of the Eucharist. By 1524 Ulrich Zwingli in Zurich had made his own dissent from the Lutheran position public. Luther's position, along with the intra-evangelical disputes, activated Catholic defense of the orthodox view. Among English writers, the debate generated a sequence of texts by representatives of the Catholic and Zwinglian positions especially. John Fisher (c. 1469-1535) Bishop of Rochester, published a defense of Catholic orthodoxy against the Lutheran view, the De veritate corporis et sanguinis Christi in eucharistia, published in Cologne in 1527.

The main documents up to Tyndale's Brief Declaration are, however, concentrated in the early 1530s, and written in English. In late 1532 John Frith composed, from the Tower, a short treatise A christen sentence... of the most honorable Sacrament, 7 to which Thomas More (1478-1535) responded with his Letter against Frith, ${ }^{8}$ ready for publication by December 1532, and published in 1533. Frith, in turn, responded to More's text (which he had read before its publication), in his A boke made by John Frith prisoner in the tower of London answeringe vnto M mores lettur (1533), a text not published until after Frith's 
execution in July $1533 .{ }^{9}$ By April 1533 another text had entered the arena, The Souper of the Lorde, ${ }^{10}$ probably by George Joye (1490/95-1553), which was in part a translation from Zwingli's De vera et falsa religione commentarius (written between 1525-1527). This text provoked Thomas More to produce his longest defense of the Catholic position, in his Answer to a Poisoned Book (published in December 1533). ${ }^{11}$ Tyndale, as we have seen, published his Brief Declaration on the Sacraments, in exile, between July 1533 and his imprisonment in May 1535.

The shape of this debate in English can be simply described: it begins as a defense of Catholic orthodoxy against Lutheran views, but had by 1530 become a battle between Catholic and Zwinglian views. Robert Barnes is the only high profile Lutheran who is considered to have held a specifically Lutheran view. In his letter of January 1533 warning John Frith to steer clear of discussion of the Eucharist, Tyndale names the Lutheran Barnes as the likely source of conflict over evangelical promotion of Zwinglian views: “Barnes will be hot against you," Tyndale warns Frith, though it is clear that Barnes is not the only potential objector. Many will be behind Barnes; as we have seen, Tyndale argues that the matter should be regarded as indifferent until it might be decided peacefully "at leisure of both parties, ${ }^{\prime 12}$ by which he means both evangelical parties disagreeing over the Eucharist. The other major English evangelical voices in this period (i.e. Frith, Joye and Tyndale) defend a Zwinglian position, fully conscious that they differ from the Lutheran view. Frith, for example, mentions that "part of the Germans do think that his natural body is present in the sacrament, and take the 
words fleshly, as Martin taught them." ${ }^{13}$ By 1532, in his Letter against Frith, and again in 1533 in his Answer to a Poisoned Book, More was defending Catholic orthodoxy against a Zwinglian, rather than against a Lutheran view.

It should also be underlined that the stakes involved were exceptionally high, not only for the nation's sacramental practice, ${ }^{14}$ but also for each polemicist involved in trying to shape that sacramental practice: each of Frith, More and Tyndale would be executed by 1536 . Frith in particular was condemned to be burned especially for his Eucharistic views. ${ }^{15}$ Frith knew very well how dangerous it was to hold and promulgate these views: in the preface to his Boke made by John Frith prisoner in the tower of London answeringe vnto M mores lettur, he says that he was unwilling to discuss the matter, but, having been asked to do so by a fellow evangelical, "I took upon me to touch this terrible tragedy, and wrote a treatise, which, besides my painful imprisonment, is like to purchase me most cruel death."16 Frith even cites his interrogation for heresy in his Articles wherefore John Frith Died: we are given access to the "terrible tragedy" of men knowingly posing doctrinal questions whose answers will condemn the holder of such views to excruciating death:

Well, said they [Frith's interrogators], do you not think that his very natural body, both flesh and blood, is really contained under the Sacrament, and there actually present, besides all similitudes? No, said I [Frith], I do not so think. 
Questions of semiotics here, what the interrogators call "similitudes," are no academic matter. Both interrogators and victim, all with full consciousness that the answers mean life or death, sort out what is real and what is figurative; one side is prepared to kill and the other to die for the "right" answers.

\section{II}

Tyndale's A Brief Declaration of the Sacraments is a quite short text (38 pages in the modern edition). ${ }^{17}$ The text is not widely read, and little discussed. ${ }^{18} \mathrm{I}$ here offer a paraphrase. Passages in square brackets are my own explications, not found in Tyndale's text.

Tyndale begins by arguing that in order to understand the sacraments, we need to understand the manner in which the ancient Hebrews set up signs of memorable events. Various examples are given, including circumcision and the blood of the Passover lamb (pp. 347-54). The blood of the paschal lamb is a prophecy of Christ (p. 355). Many things in scripture have a fulfilling in Christ, as for example the serpent of brass (p. 355), even if they were not, and could not be, understood before Christ. Had they been understood, men would have tried to prevent their being fulfilled in Christ (p. 355). The paschal lamb was a prediction of, and fulfilled by Christ's sacrifice, which is remembered by the sign of the sacrament of the "ceremony of the body and blood of Christ." This is the function of the sacrament, "to keep the death of Christ in mind" (p. 356). Rightly 
taught, rightly understood, and rightly taken, the sacrament is an "absolution of our sins" (p. 357). Sacraments, in short, serve the same function as stories of memorable events; there is "no other virtue in them, than to testify...the covenants and promises made in Christ's blood" (p. 358).

Where, however, the sacraments are not rightly practiced (as in Jewish custom), or rightly understood (as in Catholic practice), then they are positively harmful, being the cause of "their greater damnation" (358).

Both baptism and the sacrament of the altar are necessary, the last especially because the fears of hell are so great that they need the sacrament "as a sign on a high hill" to encourage the abject sinner; no man can feel the power of the blood of Christ who has not first felt the "strong pains of hell" (p. 360). The sacrament of the Eucharist is like a promise or a contract made between men, as when a man doubts the strength of a verbal commitment: the verbal promise is the more believed once it's written and sealed; so too with the sacrament: we believe the pledge all the more when the breaking of bread is seen with the eyes (pp. 360-61). Whoever witnesses a sacrament without understanding its true intent is an idolater (p. 362).

The scriptural foundations for the sacraments are cited, and the difference between the "old, cruel and fearful testament" and the New Testament is marked (p. 364). The grounding scriptural words from Matthew, Mark, Luke and Paul are cited (pp. 364-66). This might suffice; the tract might end here [says Tyndale], but "because the unquiet, scrupulous, and superstitious nature of man, wholly 
given to idolatry, hath stirred up such traditions about this one sacrament especially, I cannot but thereof speak somewhat more" (p. 366).

The three available positions are articulated [the Catholic, the Lutheran and the Zwinglian] (pp. 366-67). The third party [the Zwinglians] believe that Christ spoke figurally in the statements upon which the sacrament of the Eucharist is grounded, as when a person says "I have drunk a cup of good wine" (p.368). When Christ declared "This is my body," or when in the Gospel of John [6:48-59] Christ commands eating of his flesh in order to have eternal life, he cannot mean the sacrament, since all the Old Testament believers had eternal life, and yet did not partake of the sacrament (p. 369). Christ speaks figuratively about his presence (p. 369).

The "old doctors" disagree: sometimes they treat Christ's words literally, sometimes figuratively (p. 370). Christ was sacrificed only once; he cannot be repeatedly sacrificed in the sacrament (p. 370). The sacrament is instead a "memorial," and the "use of the scriptures is to call signs by the names of things signified thereby" (p. 371). The old doctors who promote transubstantiation did so "through false understanding," as when a man who seeks a passage in the bible looks at "paper and ink" but is in fact thinking of the "sense of his text" (p. 372).

Catholics practice idolatry; they make "God an idol or bodily image" (p. 373). Why should they kill those who believe otherwise? (p. 374), when we should "exhort each other to trust in Christ, and to love each other as Christ 
loved us" (p. 375). In matters that are as yet unclear, let us be "meek, sober, and cold" (p. 375).

The Jews are accustomed to call the "memorial and signs of things with the very name of the thing signified" (pp. 375-76). Many examples follow (pp. 375-79). The wine and bread of the Eucharist only signify, as a "sign with the name of the thing signified," the blood and flesh of Christ (p. 379).

Transubstantiation can be no necessary article of belief (p. 381). Tyndale would be prepared not to attack transubstantiation if the papists would only acknowledge "the covenant made in Christ's blood and body," and if they would leave off their "subtle sophistry and devilish idolatry" (p. 381). If they refuse to leave off, then Tyndale will deny the body of Christ to be in the sacrament (pp. 381-82). Christ could not dwell in a "crumb of bread" (p. 382). We should address God only where he wills to be addressed, just as we do not acknowledge people in the street, who gladly acknowledge us in private where acknowledgement is appropriate (p. 383). Christ can only be in one place at a time (p. 383). Many passages of scripture are susceptible of different interpretations, even if no text has "more than one single sense" (p. 384); despite disagreement among interpreters, it neither hurts nor hurts not to say that Christ's body is in the sacrament. What is dangerous is to believe that God must be prayed to in the sacrament, and to persecute "his brother for blind zeal to any opinion" (p. 385). 
There are two very striking emphases in this text: in the first sequence, Tyndale promotes in all but name Biblical figuralism, or allegory, in his account of Hebraic practice being fulfilled in Christ. In the second part, he very actively promotes figurative readings of individual passages of Scripture.

In the first part of the treatise, the allegorical, typological readings of Old Testament events affirm a commitment to Biblical allegory, a theory of the historical relation of Old and New dispensations, whereby the New recalls and fulfills the old. Throughout the rest of his oeuvre Tyndale vigorously, not to say virulently, opposes Biblical allegory. In the second part, the emphasis on figurative rhetoric affirms a readiness to read individual passages of Scripture beyond their literal sense. Elsewhere in Tyndale's oeuvre, perhaps Tyndale's most insistent emphasis in his discussion of Scripture is the completeness and selfsufficiency of Scripture's literal sense.

In short, Tyndale's insistence here on both Biblical allegory, and on figurative readings of individual passages of Scripture, is wholly at odds with his standard positions. Why should this be so? I begin with Tyndale's figurative readings of "is"; I argue that Tyndale's routine rhetorical positions are overborne by an evangelical need to tame idolatry. One we have understood why Tyndale should defend figurative readings of "is," we can broach Tyndale's uncharacteristic defense of Biblical, figural allegory in the Brief Declaration. 
What are Tyndale's standard positions on the interpretation of Scripture? Tyndale, following Luther, is relentless in his promotion of the literal sense. He does this in both large scale readings of Scripture, as he repudiates figural allegory, and in small scale readings, as he everywhere insists that the literal sense is the only sense of Scripture. Tyndale often declares that Scripture "hath but one simple, literal sense, whose light the owls cannot abide."19 Promotion of that simple, literal sense required strenuous repudiation of its competitor, allegory. Throughout his prefaces Tyndale warns his reader to "beware of subtle allegories," 20 since allegory is the surest tool the clergy can wield to preserve their own power over and possession of Scripture. "Here a man had need to put on all his spectacles, and to arm himself against invisible spirits," he says about "false allegories": they can prove nothing, and are useful only as a teaching device, used to "declare and open a text," by the use of analogy. ${ }^{21}$ Tyndale expands on the interpretive opportunity of the literal sense in the Obedience of a Christian Man (1528); he tells his reader that "the scripture hath but one sense which is the literal sense. That literal sense is the root and ground of all, and the anchor that never faileth whereunto if thou cleave thou canst never err or go out of the way." 22

Why should evangelical polemicists have so stridently championed the literal sense? This is a large question, beyond the scope of an article. I here briefly offer three possible reasons, one sociological, one academic and one explained by polemical necessity. Each one of these could bear much more expansion; my brief 
arguments here are designed simply to underline the forces driving evangelicals towards the literal sense.

Sociological. Evangelical insistence on the literal sense is part of the larger drama of modernity, a drama that is legal, commercial, and cultural as well as spiritual. As societies extend and simplify their legal and spiritual jurisdictions (as Western European societies did in the sixteenth century), so too must written authority make new claims, demolishing local custom and unwritten usage in the process. ${ }^{23}$ In any society experiencing rapidly rising populations (as Western European societies did in the sixteenth century), impersonal written forms of authority must replace the charismatic, personal force that the presence of the ruler had assumed in smaller jurisdictions. In any society undergoing profound social mobility (as Western European societies did in the sixteenth century), written authority will replace the intuitive praxis of smaller ruling elites; the new social forces habitually demand that the rules be clear (or "transparent") and explicit; they demand, in short, that the rules be written as contracts, and written in the clearest possible prose. Finally, very powerful new forms of textual reproduction (of the kind experienced by sixteenth-century Western societies), understandably mesmerize users of the new technology, who tend to fetishize it. Energized by the extraordinary new possibilities of printed books, sixteenthcentury evangelical readers affirmed written authority at the expense of both visual and non-written forms of cultural authority. ${ }^{24}$ 
Even if Tyndale could not have been expected to have been conscious of this larger textual pressure towards the literal sense, one of his examples in the Brief Declaration is symptomatic of the new and impersonal textuality. Tyndale says that sacrament is like a written contract, and gives the example of men making a promise to another "with light words between themselves"; as they separate, the one to whom the promise was made might begin to doubt the literal force of the words: perhaps the promise maker had spoken them "earnestly or mocked"; perhaps, the doubter thinks, the promise maker will not remember his promise. In such a case, the shortfall of trust is best made up with a written document: "if he strike hands, if he give earnest, if he call to record, if he give his hand-writing, and seal it; so is the promise more and more believed" (p. 361). Clear, contractual written documents diminish anxiety in a world of strangers.

Academic. Scholastic theologians, in the intensely academic environment of thirteenth-century Paris especially, devised ground rules for establishing the limits of Biblical prescription. As academic theorists tend to, they limited unbreakable authority to explicit statements, in this case made by the literal sense of the Scriptures. ${ }^{25}$ This academic rule passed noiselessly from one academic culture (that of scholasticism) to another (that of evangelical theorists), although the evangelicals coupled insistence on the literal with active repudiation of its competitor, allegory.

Tyndale gives his fullest exposition of the case against allegory and for the literal sense in his Obedience of a Christian Man. He begins by inaccurately 
summarizing the four-fold scheme of Biblical interpretation, and mocking it with the word "chopological" (p. 156). That allegorical "trash and baggage stuff" swept away, ${ }^{26}$ he proclaims his central conviction: the literal sense is the "root and ground of all" (p. 156).

Tyndale instantly goes on to make a standard scholastic point (made by Thomas Aquinas, for example), though obviously not acknowledged as a scholastic point here: that of course Scripture uses figurative language, but the meaning is clear, and that meaning is the literal sense. ${ }^{27}$ If a preacher should allegorize, it's for purely pedagogic ends, designed better to "paint" the truth. Thus the sword of Peter cutting the ear of Malchus (John 18:10) is like the Law, whereas Christ's healing is like the delivered promise of the Gospel. It is only a question of likeness, and not, we might say, of ontology: "the allegory proveth nothing neither can do" (p. 158); it's used only for psychological effect of impressing truth on the hearer, "to root it and grave it in the heart" (p. 159). So allegory is to be used with sobriety, rarely, and only "where the text offereth thee an allegory."

Of course, at this point Tyndale is required to address the fact that Paul himself uses allegory in describing the wives of Abraham as "an allegory." The wives are, says Paul, the two covenants (Galatians 4:24). It is only, however, a likeness, and it's the kind of likeness that permits Tyndale to use what look like allegories for polemical purpose: Paul uses allegory here as "likewise do we borrow likenesses or allegories of the scripture, as of Pharaoh and Herod...to 
express our miserable captivity and persecution under Antichrist the Pope" (p. 159). Acceptable, duly chastened forms of allegory once defined, Tyndale proceeds to encourage utter revulsion at any form of allegory that makes stronger than pedagogic claims: he teaches his reader how blind proponents of allegory are, "that thou mayest abhor them and spew them out of thy stomach forever" (p. 160).28

Polemical. The most obvious and powerful reason why evangelical polemicists absolutely needed to stress the limpidity of the sense is, however, polemical. Evangelical theorists needed Scripture to be clear. This was a nonnegotiable claim. Anyone claiming to reform an institution on the basis of textual authority for institutional reform needed that text to be prior to the institution. They needed the text to be unambiguous. They also needed to be able to claim that everyone could see the incontrovertible force of that unambiguous, prior textual authority. The essential polemical claim made by evangelical writers in the early sixteenth century was, therefore, that Scripture preceded the Church. ${ }^{29}$ The only verities were written verities, declared in Scripture. As Tyndale says, it is as difficult to answer the question as to which came first, Scripture or Church, as to answer the question which came first, father or son: "For the whole scripture and all believing hearts testify that we are begotten through the Word. Wherefore if the Word is the begetter of the congregation...then is the gospel before the church." ${ }^{30}$ Without that claim of absolute, non-negotiable scriptural 
priority, evangelicals were vulnerable to the authority of the institution they challenged, an institution that claimed legitimacy from unwritten traditions.

Tyndale could not have been expected to have been aware of each of these reasons, especially the first (the sociological). Neither could he afford to acknowledge each of these reasons, especially the second (the academic). But he was certainly aware of, and capable of articulating the third reason, the polemical point that Scripture precedes the Church. And if that is true, Scripture needs to be accessible and incontrovertible in its literal sense, since it would otherwise require interpretive, and therefore ecclesiastical, protocols to be understood. So the literal sense must, without negotiation of any kind, win over and exclude all others.

In short, everything Tyndale says elsewhere about the literal sense of Scripture would persuade him to read Christ's "is" literally. That this was an entirely plausible choice for him is attested to by that fact that Luther did make precisely that choice. And Luther made it for precisely the hermeneutic reason that we might expect Tyndale to make it: i.e. that the statement "This is my body" is perfectly clear and incontrovertible in its literal force. Alister McGrath says about Luther's reading of this verse that "it seemed to Luther that the whole principle of the clarity of Scripture (which he regarded as fundamental to his reforming programme at this point) was at stake over the interpretation of this verse." 31 
Why should Tyndale have broken his own most insistently reiterated rule of literal interpretation here? I suggest that his commitment to another evangelical goal, of expelling idolatry, overbears his hermeneutics here. If the bread is Christ's body, then it offers its materiality up for worship. Protestant repudiation of "works" in all their forms, and the resulting dematerialization of spiritual practice, overbears Tyndale's hermeneutics here. "Instead of teaching us to believe in Christ," says Tyndale in the Brief Declaration, about transubstantiation, they "teach us to serve Christ with bodily idolatry...And yet Christ is now a spiritual substance with the Father to be worshipped, in spirit only." Our works, done for no other purpose than to put trust in Christ, are "idolatry and image-service, and make God an idol or bodily service" (p. 373). The need to locate and expel idolatry overbears the need to read literally. Two extremely powerful evangelical commitments come into outright collision here; and repudiation of idolatry wins over commitment to the literal sense.

That victory has profound consequences for liturgical practice. The mass no longer serves as a conduit for God's grace to flow into the present of the communicant. The sacraments in particular, along with all other liturgical practices, are no longer bearers of reality so much as signs; they no longer work through "is," but rather through "signifies"; and they no longer "represent" in the literal sense of that word, so much as recall, as memorials. This recategorization of the relation of the past and present disenchants the present by making it a museum of sorts, a place of remembrance of things that happened in 
the past, somewhere else. In the Brief Declaration Tyndale is clearly determined to support his metonymic interpretation of "is" with all the philology he can muster. He cites many examples from the Hebrew Scriptures to underline the point that "The Jews are wont ever to name the memorial and signs of things with the very name of the thing signified; that the very name might the better keep the thing in mind" (pp. 375-76). He gives seventeen examples from Genesis through to Ezechiel, each an example of metonymy, and each underlining the point that the name of the place serves a memorial of a past event (pp. 375-79). When, for example, Jacob called the place where he wrestled with the angel "Phenial, God's face," he did so that "the name should keep the thing in mind" (p. 376).

The victory of memory over presence, of "signifies" over "is," became official policy even within the reign of Henry VIII. The Second Royal Injunctions of Henry VIII of 1538, for example, order bishops to destroy such images in their dioceses as are used for idolatrous purposes, and to teach their parishioners that such images serve only the purposes of remembrance: by them, the illiterate "might be otherwise admonished of the lives and conversation of them that the said images do represent; which images, if they abuse for any other intent than for such remembrances, they commit idolatry in the same, for the greater danger of their souls." 32 In the following year a proclamation declares that "neither holy bread nor holy water, candles, bows, nor ashes hallowed, or creeping and 
kissing the cross be the workers or works of our salvation, but only be as outward signs and tokens whereby we remember Christ and his doctrine." 33

This proclamation summarizes a series of regulations, in each of which the word "remembrance," or "memory" signals a recategorization: no longer do rituals serve as channels through which the past flows into the present, but instead provoke of memory. Holy water is sprinkled "to put us in remembrance of our baptism"; giving of holy bread puts "us in remembrance of unity"; the bread is made of many grains, "to put us in remembrance of the housel"; the bearing of candles on Candlemas day is done "in memory of Christ"; ashes on Ash Wednesday are given to put Christians "in remembrance of penance"; bearing of palms on Palm Sunday "reneweth the memory of the receiving of Christ." ${ }^{34}$ Key moments from the past are neutralised, or at least contained, by being described as one-off events, worthy of remembrance but without continuing operations in the present. For Tyndale, too, the sacrament is now "a memorial" of Christ's body; his determination to expel idolatry overbears his hermeneutics; "is" must mean "signifies." 35

IV

Thomas More sounds at least consonant with evangelical expositors of Scripture in his Answer to a Posioned Book, when he insists on the primacy of the 
literal sense. Attacking the Zwinglian interpretation of "is" in "This is my body," More attacks his opponents by saying that his oppoent, with his allegorycal exposycyon of spyrytuall eatynge of Chrystes godhed...goth about to take awaye the very lytterall trewth, of the very eatynge and bodily receyuynge of Christes owne very flesshe and bloud. ${ }^{36}$

On the opposite side, Tyndale, as we have seen, makes a symmetrical move: he seems to break with evangelical hermeneutics in his figurative treatment of the Eucharist.

We have so far, however, considered Tyndale's treatment only individual figures of thought, and especially of metonymy. In the Brief Declaration, Tyndale sounds even more like a traditional Catholic allegorist in his treatment of historical allegory. For even if, with respect to the Eucharist at any rate, Tyndale buys into a much more extensive application of figurative readings than Luther, that in itself does not commit him to an acceptance of typological allegory. One could accept figurative readings of individual passages without buying into the dynamic historical understanding of Old Testament events as foreshadowing and being fulfilled by their New Testament counterpart.

So far from buying into that dynamic system, Tyndale is almost everywhere vociferous in his denunciation of it. In keeping with the entire evangelical program, Tyndale described figural allegory as mere human invention laid upon and disfiguring the pure text of scripture, as the work of those who have "nailed a veil of false glosses on Moses's face, to corrupt the true 
understanding of his law." 37 In the prologue to Leviticus, for example, Tyndale holds that allegorical interpretation is a kind of interpretative anarchy. He is especially aware of this danger with regard to Old Testament ceremonies, since these come perilously close to works. Thus he forcefully repudiates allegorical interpretation, in which readers "feign every man after his own brain at all wild adventure without any certain rule." 38 In fact this anarchy suggests diabolic deception, since, Tyndale goes on,

We had need to take heed every where that we be not beguiled with false allegories, whether they be drawn out of the new testament or the old... but namely [especially] in this book [i.e. Leviticus]. Here a man had need to put on all his spectacles and to arm himself against invisible spirits. (p. 148)

The sixteenth-century assault on allegory has remained dominant in Western culture, partly because the Protestant Reformation established the literal sense as the default position; partly because humanist philology also sought to elucidate the literal sense above all; and partly because Enlightenment textuality also promoted written, contractual, and literal statements in, for example, the constitutions of France and the United States.

A moment's reflection, however, will reveal that repudiation of allegory from a hermeneutic system is easier said than done. Championing of the literal sense and only the literal sense is inevitably a convenient polemical and/or ideological posture, rather than a real possibility. The literal sense is only ever a 
fiction. Texts always say one thing and mean something else, however much literalists attempt to preserve fictions of transparency. Tyndale himself, despite strenuous efforts to repudiate allegory, admits allegory back into his Biblical interpretation. He does so in his very conception of the literal sense, ${ }^{39}$ and, as I have recently argued, he does so, with a vengeance in his treatment of the Old Testament. Whereas, however, allegory in the traditional figural scheme had been a means of historical recuperation, evangelical allegorizing becomes a waste-disposal machine..$^{40}$ In Tyndale's practice, allegory is a way of disposing, simultaneously, with Hebraic custom and Catholic observance. ${ }^{41}$

In the Obedience of a Christian Man, for example, Tyndale begins by violent repudiation of allegory. The cause of the Church's current captivity "sprang first of allegories"; the reader must understand the sophistry and blindness of allegories, in order, as we saw above, that "thou mayest abhor them and spew them out of they stomach forever." 42 That point made, he encourages, as he does elsewhere, ethical readings of the Old Testament. ${ }^{43}$ Thus with the "homely gest" of Noah's drunkenness: Tyndale's reader will remember what happened to the “cursed children of wicked Ham which saw his father's privy members and jested thereof to his brethren" (p. 163). Readings of this kind are very close to the so-called "tropological" or moral sense of the four-fold scheme, even if Tyndale subtly shifts such readings from being strictly ethical to being replays of the drama of salvation: "thou seest what infirmity accompanieth God's elect be they never so holy, which is yet not imputed to them" (p. 164). 
That Tyndale should make tropological readings is entirely unsurprising. What is surprising is that he should then go on to make spectacular allegorical readings. He proceeds, in this case, to read the story of Ham mocking his father's nakedness in the most startling series of allegorical connections. The narrative provides "an apt and handsome allegory...to describe our wicked Ham, Antichrist the Pope." For just as Ham mocked his father's nakedness, so too for hundreds of years has the Pope, as Anti-Christ, "done all the shame that heart can think unto the privy member of God, which is the word of promise or the word of faith...and the gospel and testament of Christ wherewith we are begotten" (p. 164). The identification of Noah's penis and the Gospel is startling enough, but Tyndale goes on from here to develop the connection between Ham and the Pope in a dazzling series of Old Testament "similitudes": just as the descendants of Ham grew into giants, so too have the Pope and his minions become "mighty giants above all power and authority." One of the descendants of Ham was Nimrod; Tyndale expects his readers to know this, since he goes on thus: "They [the Pope and his minions] heap mountain upon mountain, and will to heaven by their own strength." Just as God destroyed these giants, so too will he destroy the Pope.

After this bravura display of Old Testament references woven into an allegorical narrative, Tyndale settles once again into sober, anti-allegorical mode: “The similitudes prove nothing, but are made to express more plainly that which is contained in the scripture and to lead thee in the spiritual understanding of the 
text." 44 This move looks rather like special pleading: allegory proves nothing except the true meaning of the text. Insofar as Tyndale is effectively saying that, he is borrowing the interpretative and poetic ingenuity of his opponents. We should note, however, that Tyndale uses allegory only to repudiate.

So for Tyndale historical allegory does not exist in theory at all; allegory is either a teaching device, which makes no historical claim whatsoever. In practice, allegory serves to target Catholic custom via Hebraic custom and vice versa. So what of the Brief Declaration? Just as we find a very unusual affirmation of figurative language, so too do we find a striking affirmation of historical allegory, or figuralism. Tyndale nowhere uses the word "allegory," but there can be no doubt but that he is offering a relatively straightforward account of figuralism.

The pesah, or sacrificial lamb, was not only a seal of God's promise; it was also, says Tyndale, "a very prophecy of the passion of Christ, describing the very manner and fashion of his death, and the effect and virtue thereof also" (p. 354). Tyndale draws imagistic, metaphorical connections between the Passover and the Crucifixion, in exactly the manner of a figural interpretation: “The blood striken on the posts saved them, that they were not plagued with the Egyptians, and delivered them out of the captivity of Pharao. And the blood of Christ, striken on the posts of our consciences with a sure faith, delivereth us from the captivity of the Devil" (p. 354). Tyndale does not stop at likeness here: he affirms that the Passover was not only a "very prophecy of the death of Christ," but that 
Christ's breaking of the bread points to the fulfilling of the Passover; the breaking of the bread "hath yet another signification, hitherto unknown unto you, which must be fulfilled spiritually in the kingdom of God by my passion" (p. 355). Many things in Scripture, Tyndale goes on, “

which have a carnal fulfilling... and yet have another spiritual signification, to be fulfilled long after in Christ and his kingdom, and yet never known till the thing be done. As the serpent of brass which Moses hanged up in the wilderness, yet it so describeth the lifting up of Christ upon the cross...that no tongue could better declare it, to make the heart feel it (p. 355).

These are remarkable statements, which seem to me to overturn everything Tyndale says elsewhere about figural allegory. It is true that he immediately goes on to deny that these figural prophecies were in any way legible before their fulfillment (p. 357). Even more severely, he immediately goes on to say that the spiritual fulfillment of the sacrificial lamb "ended there" (pp. 355-56). So now the sacrament is a sign, not a further fulfillment (p. 356). More severely still, he affirms that anyone who receives the sacraments improperly does so to "their greater damnation" (p. 358). Having given a very committed account of figural allegory, Tyndale attempts to contain its force: no-one could have read it, and it has no ongoing current in history; it ended with the crucifixion, and what we have left are pedagogic signs (of the Eucharist); anyone who sees it as an ongoing, repeated historical event is an idolater. 
In short, in his discussion of the Eucharist Tyndale is strikingly open to what is, initially at any rate, an unreconstructed version of figural allegory. Why this should be so I can only speculate, which is what I do in conclusion to this essay.

Tyndale's historical view of the Eucharist as a memorial sign transforms the world into a memorial, a site from which the currents of history have ceased to flow. Transformative one-off events, and notably the Crucifixion, must be remembered, not re-experienced. Present experience no longer allegorically replays and fulfills the past. One difficulty with this banishment of figural allegory is that the Hebrew Scriptures are threatened with irrelevance. If only the literal sense matters, and if there is no allegorical sense in the Old Testament, then why are we reading the Old Testament, apart from the explicit covenants? No ancient text can be taken literally and remain pertinent to contemporary readers. This is especially true of the narrative of the Hebrew Scriptures: if we read it literally, then does it have any significance for the present at all? In my view the consequences of this position were too destructive for Tyndale to contemplate. For if the Hebrew Scriptures did not allegorically prophesy Christ, and if Christ's own sacrifice can only be remembered, not repeated, then history starts to collapse: there are no currents in history, just a single moment of overwhelming historical significance (the Crucifixion) without precedent or ongoing effects in the future. 
In a matter as cardinal as the Eucharist, the Hebrew Scriptures had both to prophesy and to be fulfilled. The moment they were fulfilled, then history stopped, but if they had not been fulfilled just that one time, then all of history apart from the moment of Christ was threatened with irrelevance. In his discussion of the Eucharist, Tyndale's inconsistent affirmation of figurative reading of "is" produces a complementary, and equally inconsistent affirmation of figural allegory.

In the following notes, references to "image" number designate the image number of the facsimile edition in the electronic archive Early English Books Online.

${ }^{1}$ The work is edited (under the title A Fruitful and Godly Treatise Expressing the Right Institution and Usage of the Sacrament of Baptism and the Sacrament of the Body and Blood of Our Saviour Jesu Christ) in Doctrinal Treatises and Introductions to Different Portions of the Holy Scriptures by William Tyndale ed. Henry Walter, Parker Society (Cambridge: Cambridge University Press, 1848), pp. 347-85. I use an abbreviated form of the title (A briefe declaration of the sacraments) under which the text was published in 1548. For Tyndale's biography, see David Daniell, William Tyndale, A Biography (New Haven: Yale University Press, 1994). On p. 220, Daniell repeats the statement by Walter that the text was printed in 1533 , 
though it is unclear to me in either text as to what the evidence for that precise date is.

2 The letter was first published by John Foxe in his 1563 edition of Acts and Monuments. It is edited in The Work of John Frith, ed. N. T. Wright, The Courtenay Library of Reformation Classics, 7 (Oxford: Sutton Courtenay Press, 1978), pp. 492-96 (at p. 493).

${ }^{3}$ STC 24445.

${ }^{4}$ Martin Luther, The Babylonian Captivity of the Church, in Luther's Works 36, Word and Sacrament 2, ed. Abdel Ross Wentz (Philadelphia: Fortress Press, 1959), pp. $11-126$.

${ }^{5}$ For more detailed discussion of the Lutheran view compared with that of Zwingli, see David C. Steinmetz, “Scripture and the Lord's Supper in Luther's Theology," in his Luther in Context (Bloomington, IN: Indiana University Press, 1986), pp. $72-84$.

${ }^{6}$ For a detailed account of the development of Zwingli's view, see W. P. Stephens, The Theology of Huldrych Zwingli (Oxford: Clarendon Press, 1986), Chapter 11 “The Eucharist." For a succinct summary of all the relevant positions, see Alister E. McGrath, Reformation Thought, third edition (Oxford: Blackwell, 1999), pp. 174-90.

${ }^{7}$ STC 5190. The text is edited in The Work of John Frith, ed. Wright, pp. 477-84. 8 STC 18090. The letter is edited in The Correspondence of Sir Thomas More, ed. Elizabeth Frances Rogers (Princeton: Princeton University Press, 1947), no. 190. 
${ }_{9}^{9}$ STC 11381. The text is edited in The Work of John Frith, ed. Wright, pp. 319-449. ${ }^{10}$ STC 24468. The text is edited in Thomas More, The Answer to a Poisoned Book, ed. Stephen Merriam Foley and Clarence H. Miller, The Complete Works of St Thomas More, 11 (New Haven: Yale University Press, 1985), Appendix A. ${ }^{11}$ For a magisterial account of the Eucharistic debate in England, set in its Continental context, leading up to and including More's Answer to a Poisoned Book, see Stephen Merrian Foley and Clarence H. Miller, “The Shape of the Eucharistic Controversy," in The Answer to a Poisoned Book, ed. Foley and Miller, xvii-lxi. The preceding paragraph is wholly dependent on this essay. 12 The Work of John Frith, ed. Wright, p. 493.

${ }^{13} \mathrm{~A}$ boke made by John Frith prisoner in the tower of London answeringe vnto M mores lettur, in The Work of John Frith, ed. Wright, p. 413.

${ }^{14}$ It should be mentioned that the Zwinglian view did become national sacramental policy in England. In 1552, these words added to the first, 1549 Book of Common Prayer: "Take and eate this, in remembrance that Christ died for the, and fede on him in thy heart by faith," Book of Common Prayer (London: Grafton, 1552) (STC 16284.5), image 131. The 1563 formulation of the Thirty-Nine Articles are clear in their repudiation of transubstantiation and in their affirmation of the purely spiritual nature of the Eucharistic meal:

Transubstantiation, or the change of the substance of bread and wyne, into the substance of Christ's body and bloud, cannot be proved by holy writ: 
But is repugnant to the plain wordes of scripture, perverteth the nature of a sacrament, and hath given occasion to many superstitions.

The body of Chryst, is geven, taken and eaten in the supper, after a heavenly and a sprituall manner onely. But the meane wherby the bodye of Chryste is received, and eaten in the supper, is faith.

Cited in "The Thirty-Nine Articles," in this edition: Articles. wherevpon it was agreed by the archbysshops and bisshops of both the prouinces, and the whole clergye, in the conuocation holden at London in the yere of our Lord God M.D.lxii (London: Richard Jugge and John Cawood, 1563) (STC 10038.3), image 15. ${ }^{15}$ See Frith's The Articles wherefore John Frith Died, which he wrote in Newgate the 23d day of June, the year of our Lorde 1533, in The Work of John Frith, ed. Wright, pp. 450-55. For Frith's biography and condemnation, see "John Frith," in The Oxford Dictionary of National Biography, consulted at www.oxforddnb.com.ezp1.harvard.edu/subscribed/. ${ }^{16}$ A boke made by John Frith prisoner in the tower of London answeringe vnto M mores lettur, in The Work of John Frith, ed. Wright, p. 322.

${ }_{17}$ Page references here and elsewhere in this article to A Brief Declaration of the Sacraments will be inserted in the body of the text. Page references are to $A$ Fruitful and Godly Treatise, in Doctrinal Treatises, ed. Walter. 18 The one modern discussion is Eric Lund, "Tyndale and Frith on the Eucharist as Sign and Memorial," in Word, Church and State: Tyndale Quincentenary Essays, 
ed. John T. Day, Eric Lund, and Anne M. O'Donnell (Washington: Catholic University Press of America, 1998), pp. 183-96. Lund outlines positions, without remarking on their unusual character.

19 "The Preface of Master William Tyndale that he made before the Five Books of Moses called Genesis," in William Tyndale, Tyndale's Old Testament, ed. David Daniell (New Haven: Yale University Press, 1992), pp. 3-4.

20 "A Prologue into the Second Book of Moses called Exodus," in Tyndale, Tyndale's Old Testament, ed. Daniell, p. 84.

21 "A Prologue into the Third Book of Moses called Leviticus," in Tyndale's Old Testament, ed. Daniell, p. 148.

22 William Tyndale, The Obedience of a Christian Man, ed. David Daniell (London: Penguin, 2000), p. 156. Further references to the Obedience in this chapter will be made by page number in the body of the text.

${ }^{23}$ For the later medieval history of written legal and theological documents impersonally applied, see Brian Stock, The Implications of Literacy: Written Language and Models of Interpretation in the Eleventh and Twelfth Centuries (Princeton: Princeton University Press, 1983); M. T. Clanchy, From Memory to Written Record: England 1066-1307, second edition (Oxford: Blackwell, 1993), and Richard Firth Green, A Crisis of Truth: Literature and Law in Ricardian England, (Philadelphia: University of Pennsylvania Press, 2002). For the textual implications of what I here call the "drama of modernity," and the struggle of the written versus the unwritten, see also James Simpson, Burning to Read: English 
Fundamentalism and its Reformation Opponents (Cambridge, MA: Harvard University Press, 2007), Chapters 4 and 7.

24 The standard work for the cultural significance of the introduction of printing remains Elizabeth Eisenstein, The Printing Press as an Agent of Change, 2 vols. (Cambridge: Cambridge University Press, 1979).

25 See, for example, Thomas Aquinas (d. 1274): “...Holy Scripture sets up no confusion, since all meanings are based on one, namely the literal sense. From this alone can arguments be drawn, and not...from the things said by allegory." See St Thomas Aquinas, Summa Theologiae, ed. Thomas Gilby, 60 vols. (London: Eyre and Spottiswoode, 1968), 1a.1.10, 1:39.

26 The words are those of Nicholas Udall, in his translation of Erasmus' Paraphrase of the New Testament; see Desiderius Erasmus, The first tome or volume of the Paraphrase of Erasmus upon the newe testamente (London, 1548), RSTC, 2854.4, image 10.

27 Aquinas, Summa Theologiae, ed. Gilby, 1a 1,10, 1:40.

28 See further, Simpson, Burning to Read, Chapter 4.

${ }^{29}$ For the late medieval and Reformation relation between Scripture and the Church, see George H. Tavard, Holy Writ or Holy Church? (London: Burns and Oates, 1959). See further Simpson, Burning to Read, Chapter 7.

30 William Tyndale, An Answer unto Sir Thomas Mores Dialogue, ed. Anne M. O'Donnell and Jared Wicks (Washington: The Catholic University of America Press, 2000), p. 23. 
31 McGrath, Reformation Thought, p. 179.

${ }^{32}$ For a conspectus of Henrician and Edwardian legislation against images, see Margaret Aston, England's Iconoclasts, vol. 1: Laws Against Images (Oxford: Clarendon Press, 1988), pp. 223-300.

33 In Tudor Royal Proclamations, ed. P. L. Hughes and J. F. Larkin, 3 vols. Vol. 1: The Early Tudors (1485-1553) (New Haven: Yale University Press, 1964), no. 188, p. 279.

${ }^{34}$ Tudor Royal Proclamations, ed. Hughes and Larkin, 1: no. 188, pp. 278-9. For discussion of these Proclamations, see Eamon Duffy, The Stripping of the Altars: Traditional Religion in England, 1400-1580 (New Haven: Yale University Press, 1992), Chapter 11. For a larger account of the new function of memory in Henrician England, see James Simpson, “Diachronic History and the Shortcomings of Medieval Studies," in Reading the Medieval in Early Modern England, edited by David Matthews and Gordon McMullan (Cambridge: Cambridge University Press, 2007, forthcoming).

35 For a parallel, though much more systematic evangelical rhetoric, which overturns evangelical commitment to the literal sense at every turn, see the fascinating text by Thomas Swynnerton, written between 1536 and 1540: A Reformation Rhetoric: Thomas Swynnerton's "The Tropes and Figures of Scripture," ed. Richard Rex (Cambridge: RTM Publications, 1999). See in particular, under "Metonymia," the section devoted to "after what maner the sacraments do 
Iustify": "Metonymia also is when we gyve that power and virtue, to the Sacrementes, which properly belongeth to the things signified by them" (p. 135). ${ }^{36}$ More, Answer to a Poisoned Book, ed. Foley and Miller, Book 1.3, p. 18. 37 William Tyndale, The Pathway into the Holy Scripture, in William Tyndale, Doctrinal Treatises and Introductions to Different Portions of the Holy Scriptures, ed. Henry Walter (Cambridge: Cambridge University Press, 1848), p. 28. ${ }^{38}$ Tyndale, Tyndale's Old Testament, ed. Daniell, p. 148. All further reference to Tyndale's Old Testament in this chapter will, unless otherwise specified, be made by page number in the body of the text.

${ }^{39}$ For the ineluctability of allegory, with especial regard to Tyndale, see Mary Jane Barnett, "From the Allegorical to the Literal (and Back Again): Tyndale and the Allure of Allegory," in Word, Church and State: Tyndale Quincentenary Essays, ed. John T. Day, Eric Lund, and Anne M. O’Donnell (Washington: Catholic University Press of America, 1998), pp. 63-73.

40 See further Simpson, Burning to Read, Chapter 6.

${ }^{41}$ Luther also frequently made the identification of Jewish and Catholic practice. See Heinrich Bornkamm, Luther and the Old Testament, trans. Eric W. and Ruth C. Gritsch (Philadelphia: Fortress Press, 1969): “The godless arrogance of the Jews was nothing but the haughtiness of the Roman Church of [Luther's] day" (p. 19). For a routine example of the alignment of Jewish idolatry with Catholic idolatry, see Martin Luther, "Preface to the Prophets," in Luther's Works 35, Word and Sacrament 1, ed. E. Theodore Bachmann (Philadelphia: Muhlenberg Press, 1960), 
pp. 265-278 (at pp. 268-273). For a full range of Jewish hermeneutic practices and religious observances being lined up with Catholic practices, see also Tyndale, "Prologue to the Prophet Jonah," in Tyndale, Tyndale's Old Testament, ed. Daniell, pp. 636-637.

${ }^{42}$ Tyndale, The Obedience of a Christian Man, ed. Daniell, p. 160.

${ }^{43}$ For other examples of tropological readings in Tyndale, see Tyndale, Tyndale's Old Testament, ed. Daniell, pp. 8 and 85.

${ }^{44}$ Tyndale, The Obedience of a Christian Man, ed. Daniell, pp. 164-65. 